\title{
Multiscale Thermal Hydraulic Study under the Inadvertent Safety Injection System Operation Scenario of Typical Pressurized Water Reactor
}

\author{
Mingjun Wang, Qiaolin Zuo, Hao Yu, Wenxi Tian, G. H. Su, and Suizheng Qiu \\ Department of Nuclear Science and Technology, Xian Jiaotong University, Xi'an, China \\ Correspondence should be addressed to Suizheng Qiu; szqiu@mail.xjtu.edu.cn
}

Received 16 July 2017; Accepted 10 September 2017; Published 18 October 2017

Academic Editor: Iztok Tiselj

Copyright (c) 2017 Mingjun Wang et al. This is an open access article distributed under the Creative Commons Attribution License, which permits unrestricted use, distribution, and reproduction in any medium, provided the original work is properly cited.

\begin{abstract}
The Reactor Pressure Vessel (RPV) inlet nozzles and downcomer wall in Pressurized Water Reactors (PWR) may suffer serious thermal shock caused by cold water from reactor Safety Injection System (SIS) in some unexpected accident scenarios. It implies the formation of great temperature gradient on the inlet nozzles and RPV wall, leading to the localized stresses and propagation of possible flaws that appeared in the material. In this paper, the multiscale thermal hydraulic analysis was performed for Chashma Nuclear Power Plant (NPP) under the inadvertent SIS operation scenario. The primary loop and SIS were modeled using onedimensional method, while the three-dimensional models of reactor cold leg, RPV inlet nozzles, and downcomer were established. Then, the inadvertent Safety Injection System operation scenario was simulated using RELAP5 code, providing the boundary conditions for three-dimensional Computational Fluid Dynamics (CFD) analysis. The fluid and solid coupling heat transfer simulation method was employed. Results show that the maximum temperature difference was about $80 \mathrm{~K}$ in the most conservative condition and the RPV inlet nozzle region was the most critical region during the accident. This work could provide in-depth understanding on the effect of cold coolant injection along the main pipes and RPV wall during the accident scenario.
\end{abstract}

\section{Introduction}

The Pressurized Thermal Shock (PTS) phenomenon study for Pressurized Water Reactor (PWR) has been a hot research topic for several decades. PTS is identified as one of the most important Nuclear Reactor Safety (NRS) issues since the primary loop boundary is one of the barriers against fission product release. In the event of Loss of Coolant Accident (LOCA) or some unexpected accident scenarios, the cold injection water from Safety Injection System (SIS) or Emergency Core Cooling (ECC) system flows to the cold leg and Reactor Pressure Vessel (RPV) downcomer, leading to the material rapidly cooling and great thermal loads on the reactor main pipes and RPV under pressurized conditions. The thermal stress is induced during the process and it would threaten the RPV structure integrity [1]

Generally, the PTS thermal hydraulic study is involved in the complex system operation and local detailed threedimensional analysis. Therefore, the combination of different thermal hydraulic analysis scales is necessary in order to achieve more reliable results. The one-dimensional system analysis is used to study system performance during the transient scenarios. However, it could not give detailed threedimensional temperature distributions of key components. The Computational Fluid Dynamics (CFD) study could achieve the detailed three-dimensional fluid-solid coupling heat transfer features, but currently it could not realize a long time scale transient calculation for a complex structure, such as reactor, due to the computational resources limit. Therefore, the multiscale method was adopted for the PTS thermal hydraulic study under the inadvertent Safety Injection System operation scenario of typical PWR in this work.

The nuclear power plant one-dimensional safety analysis is widely implemented using system codes, such as RELAP5, TRACE, and TRAC, which has been accepted by scholars around the world. In recent years, one of the main applications of CFD method for NRS is the PTS study, which is regarded as high priority in the Phenomena Identification 


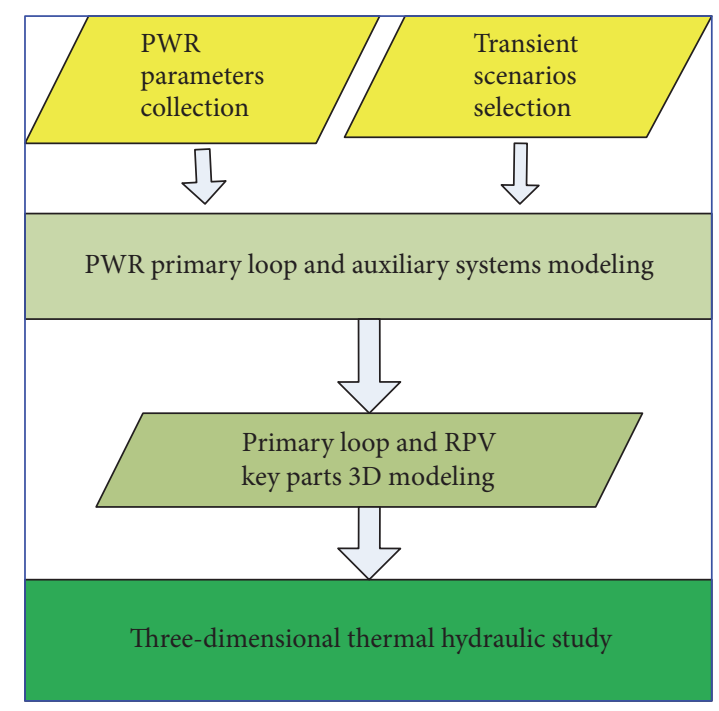

FIGURE 1: The procedure diagram of multiscale thermal hydraulic study.

and Ranking Table (PIRT) [2]. Therefore, most scholars focused on the detailed coolant mixing mechanism study for either single-phase or two-phase flow. The flow mixing in the PWR downcomer and lower plenum was studied using both experiment and CFD methods. It has been shown that the developed CFD model provided a good agreement with experiment $[3,4]$. The NEPTUNE CFD 1.0.8 is a twophase three-dimensional thermal hydraulic code and much validation work for PTS applications has been performed [5, 6]. This work substantiated the application of the tool for PTS studies. The specific large interfaces closure laws developed and implemented in NEPTUNE CFD considered not only the cells crossed by the large interface but also the two neighboring cells located in large interfaces normal direction $[7,8]$. Onizawa et al. [9] made great efforts on the Probabilistic Fracture Mechanics (PFM) analysis code PASCAL (PFM Analysis of Structural Components in Aging LWR), which was developed at JAEA to evaluate the conditional failure probability of a RPV containing a flaw under transient conditions such as PTS. Some functions of PASCAL were improved such as the Monte Carlo method and the probability of crack detection by inspection and the graphical user interface. Jang [10] performed the sensitivity study of the thermal hydraulic for PTS study. In his work, the existing PFM code was modified to incorporate the uncertainties in thermal hydraulic inputs for the PFM analysis. The effects of uncertainties in the thermal hydraulic inputs for vessel failure probabilities were evaluated using the modified code. For the PTS accident scenarios selection, Woods et al. [11] described the process used to identify the PTS risk significant events for the Nuclear Regulatory Commission (NRC) PTS risk evaluation.

As stated above, some literatures were focused on the nuclear power plant transient safety analysis, while some were concentrated on the specific coolant mixing phenomenon study in a limited time scale. Very rare research was given consideration to the multiscale thermal hydraulic study for the reactor long time simulation. In this paper, the Chashma Nuclear Power Plant (NPP) was taken as the research object.
The Reactor Coolant System (RCS) and the SIS were modeled using the RELAP5 code firstly $[12,13]$. The inadvertent Safety Injection System operation transient scenario was simulated and investigated. The variations of important parameters with time were achieved, such as the flow rates and temperatures of injection water and primary loop coolant. Then onedimensional analysis results were fitted as the polynomial and taken as the boundary input conditions for the CFD calculation. The commercial CFD software ANSYS-CFX [14] was utilized to simulate the detailed three-dimensional temperature fields of the inlet nozzles, T-junction, and RPV downcomer. The results achieved in this work could be used as the input for the RPV stress analysis and the structure integrity assessment.

\section{Multiscale Methods}

The procedure of multiscale thermal hydraulic study for Chashma NPP is shown as Figure 1. The one-dimensional and three-dimensional thermal hydraulic studies are performed sequentially to achieve the reliable temperature distributions, which could be taken as the inputs for stress analysis and structure integrity assessment for reactor key components.

The transient behavior of Chashma NPP was studied under the inadvertent Safety Injection System operation scenario. The temperatures of primary loop and SIS and flow rates of primary loop and SIS achieved through onedimensional study were handled using MATLAB software as the inputs for the boundary and initial conditions of CFD simulation. Then the detailed thermal hydraulic characteristics of the primary loop cold leg inlet nozzles and RPV downcomer were obtained.

\section{System Analysis}

3.1. RCS Model. The Chashma NPP is a two-loop type PWR and the RCS was divided into several important parts according to the basic principles and processes of 
TABLE 1: The main parameters of Chashma NPP.

\begin{tabular}{lc}
\hline Parameters & Value \\
\hline Reactor thermal power & $998.6 \mathrm{MW}$ \\
Operation pressure & $15.2 \mathrm{MPa}$ \\
Arrange type of fuel assembly & $15 \times 15$ \\
SG pressure (full power) & $5.4 \mathrm{MPa}$ \\
Reactor type & $2 \mathrm{Loops} \mathrm{PWR}$ \\
Reactor outlet temperature & $315.5^{\circ} \mathrm{C}$ \\
Reactor inlet temperature & $288.5^{\circ} \mathrm{C}$ \\
Thermal designed flow rate & $3227.896 \mathrm{~kg} / \mathrm{s}$ \\
Steam flow rate (each SG) & $280.56 \mathrm{~kg} / \mathrm{s}$ \\
\hline
\end{tabular}

primary coolant system during system modeling, including the reactor core, pressurizer and pressure control system, steam generators, main pumps, and the corresponding pipes and valves. The diagram of RCS and RELAP5 nodalization is shown as Figure 2. The detailed nodalization description was introduced in the author's previous paper [15]. The main parameters of Chashma NPP are listed in Table 1.

3.2. SIS Model. There are four high-pressure-safety-injection pumps in high pressure SIS, two of which compose a group whose inlets are connected to the refueling water tank through check valves and power-operation-isolation valves. All the inlets in the same group are connected to the outlets of the shutdown-margin pumps through power-operationisolation valves. The outlets are connected to a header pipe which is divided into four branch pipes. The four pipes are connected to the cold legs or hot legs of RCS.

Under the condition of safety injection, the high-pressure-safety-injection pumps pump cold water from the refueling water tank to the reactor core. During the recirculation phase, the high-pressure-safety-injection pumps work as supplement of low pressure safety injection pumps, to pump the water in the containment sump back to the reactor core. The RELAP5 nodalization diagram of Chashma NPP SIS is shown as Figure 3.

3.3. One-Dimensional Model Verification. Generally, The RELAP5 code is a general transient analysis program for thermal hydraulic system and its application scope includes coolant loss accidents, running transient state, power supply lose, flow loss, and subcooling transient state. The RELAP5 code has been widely accepted for the system safety analysis of nuclear power plants. For a special work, the steadystate simulation could be used to verify the feasibility of the built RELAP model and the transient scenarios are simulated based on the steady state with the "Restart function"; in this paper, the steady-state simulation of Chashma NPP was performed firstly to verify the RELAP5 model established in this work. The whole system calculation reached steady state at about $3460 \mathrm{~s}$. The comparisons between the calculation results and the rated full-power operation parameters obtained from the Chashma NPP design report are shown in Table 2. As can be seen in the table, the RELAP5 calculated values were in good agreement with the rated values. The maximum steady errors of key parameters are less than $2.0 \%$, which is in the acceptable range. This demonstrates that the RELAP5 model established above is accurate and reliable. Based on the steady calculation model, the transient scenario was studied in the following section.

3.4. Inadvertent Safety Injection System Operation. In this section, one-dimensional safety analysis of inadvertent Safety Injection System operation was simulated. The variations of SIS and primary loop coolant flow rates and temperatures with time were studied. In the scenario of inadvertent Safety Injection System operation, due to the unexpected action of the Safety Injection System valves, the cold water in SIS was injected into the reactor primary loop and the thermal shock damage would happen. According to the operating experience of nuclear power plant, this type accident has a relatively high frequency.

According to the logic of inadvertent Safety Injection System operation accident, the Safety Injection System was acted by mistake at $100 \mathrm{~s}$. Then the reactor shuts down and the main pumps run out. The steam generator secondary water supply switched from the main water supply system to the auxiliary feed-water system after the trip signal. The important thermal hydraulics characteristics results are shown in Figures 4 and 5.

The variations of flow rates and coolant temperatures in Safety Injection System and primary loop during the accident scenario were shown in the figures. The reactor shuts down immediately receiving shut-down signal after inadvertent Safety Injection System operation. The cold water from Safety Injection System began to be injected into primary loop, leading to rising of the primary loop pressure, making the safety injection flow rate decrease. The maximum injection flow rate was about $13 \mathrm{~kg} / \mathrm{s}$. The coolant temperature declined from the beginning of this scenario. In this case, the thermal shocks could be loaded on the reactor cold leg inlet nozzles and RPV downcomer and it would bring great threat to the reactor safe operation.

\section{CFD Simulation}

In order to achieve the detailed three-dimensional temperature distributions of RPV inlet nozzles and downcomer wall, the CFD work was performed and the conjugate heat transfer simulation method was adopted to handle the coupling phenomenon between fluid region and solid region.

4.1. Geometry Model. The detailed three-dimensional models of Chashma NPP primary loop cold pipes and the RPV downcomer were established, as shown in Figure 6. The detailed RPV parameters are listed in Table 3. Considering the inlet effect, the length of inlet tube was extended. The fluid region and solid region geometry were generated separately for the fluid-solid coupling study. In this work, because the RPV lower plenum, the reactor core, and the upper plenum are not the research focus, they were all simplified using the equivalent resistance method.

4.2. Gridding. The hexahedral mesh with refined meshes near the wall was generated using ICEM software for the cold legs, 


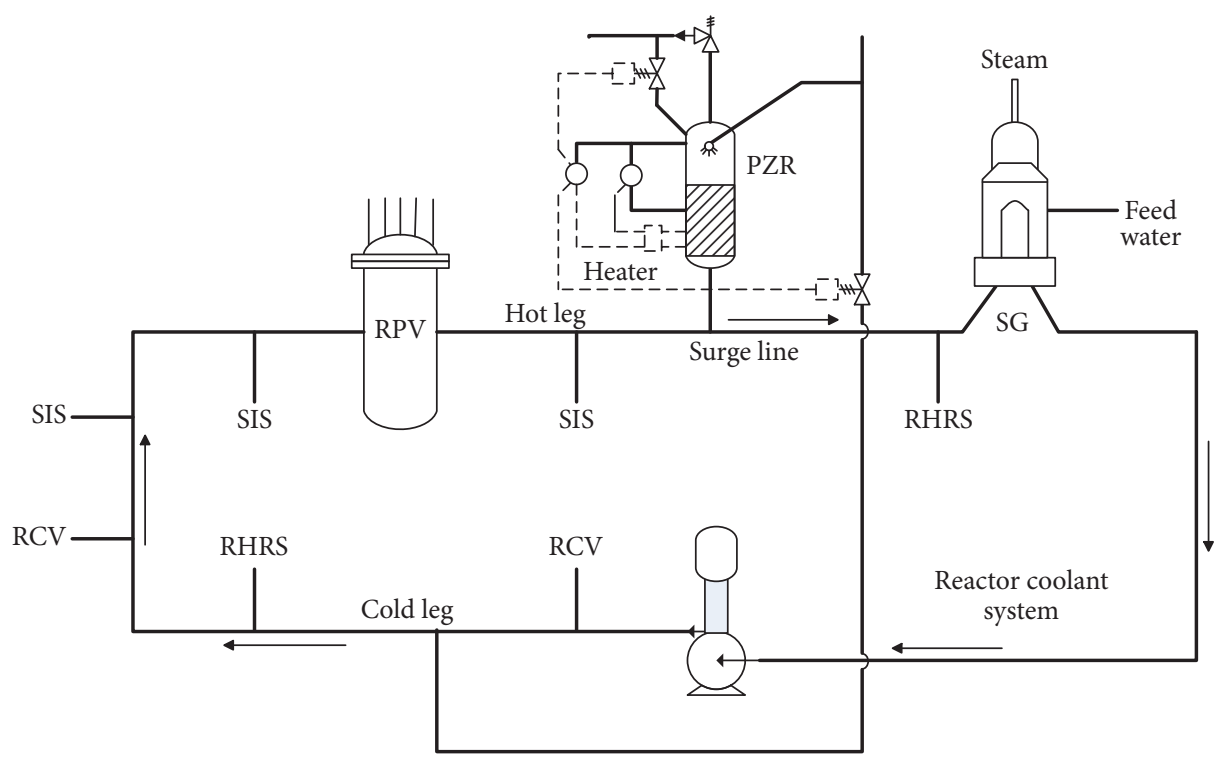

(a) Schematic diagram

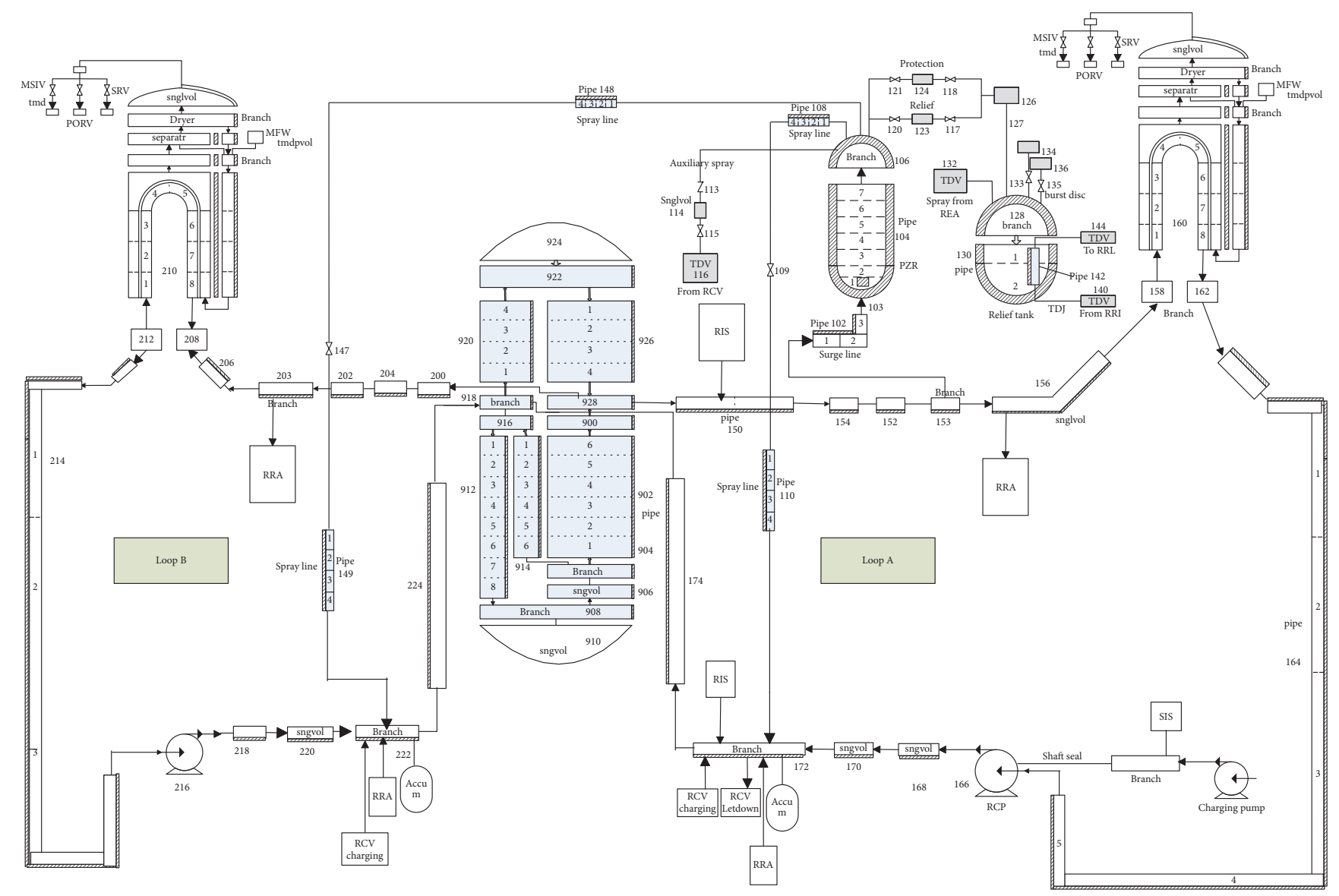

(b) Nodalization

FIgURE 2: The Chashma NPP RCS and RELAP5 nodalization diagram. 
TABLE 2: Steady calculation results and comparison with design value.

\begin{tabular}{lccc}
\hline Parameters & RELAP5 value & Design value & Error \\
\hline Primary loop pressure $(\mathrm{MPa})$ & 15.26 & 15.2 & $0.39 \%$ \\
Reactor outlet temperature $\left({ }^{\circ} \mathrm{C}\right)$ & 316.1 & 315.5 & $0.19 \%$ \\
Reactor inlet temperature $\left({ }^{\circ} \mathrm{C}\right)$ & 289.0 & 288.5 & $0.17 \%$ \\
Primary flow rate $(\mathrm{kg} / \mathrm{s})$ & 3230.25 & 3227.896 & $0.07 \%$ \\
SG mass flow rate $(\mathrm{kg} / \mathrm{s})$ & 283.62 & 280.56 & $1.09 \%$ \\
SG pressure $(\mathrm{MPa})$ & 5.544 & 5.54 & $0.07 \%$ \\
Upper plenum flow rate $(\mathrm{kg} / \mathrm{s})$ & 31.65057 & 32.2788 & $1.94 \%$ \\
\hline
\end{tabular}

TABLE 3: The main parameters of RPV.

\begin{tabular}{lcc}
\hline Parameters & Unit & Value \\
\hline Designed pressure & $\mathrm{Mpa}$ & 17.16 \\
Designed temperature & ${ }^{\circ} \mathrm{C}$ & 350 \\
Shell material & $/$ & $\mathrm{mm}-508 \mathrm{Cl}$ \\
Total height & $\mathrm{mm}$ & 10705 \\
Barrel outer diameter & $\mathrm{mm}$ & $\Phi 3732$ \\
Shell inner diameter & $\mathrm{mm}$ & $\Phi 3374$ \\
Shell wall thickness & $\mathrm{m}$ & 175 (without reactor weld layer 4 mm) \\
Total volume & $\mathrm{mm}$ & 74.47 \\
Junction inner diameter & $\mathrm{mm}$ & $\Phi 700$ \\
Junction outer diameter & & $\Phi 1050$ \\
\hline
\end{tabular}

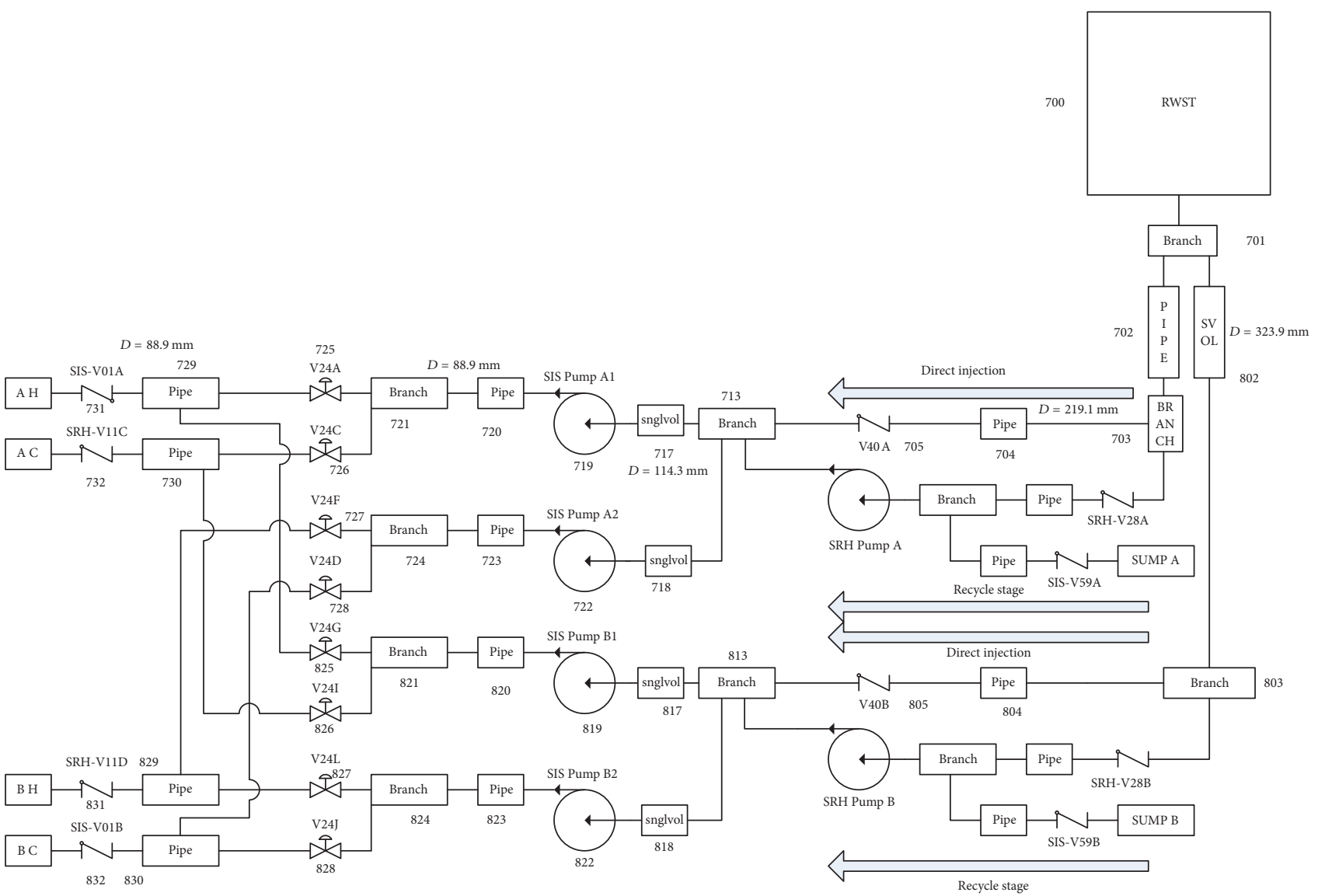

FIgURE 3: The RELAP5 nodalization of Safety Injection System. 

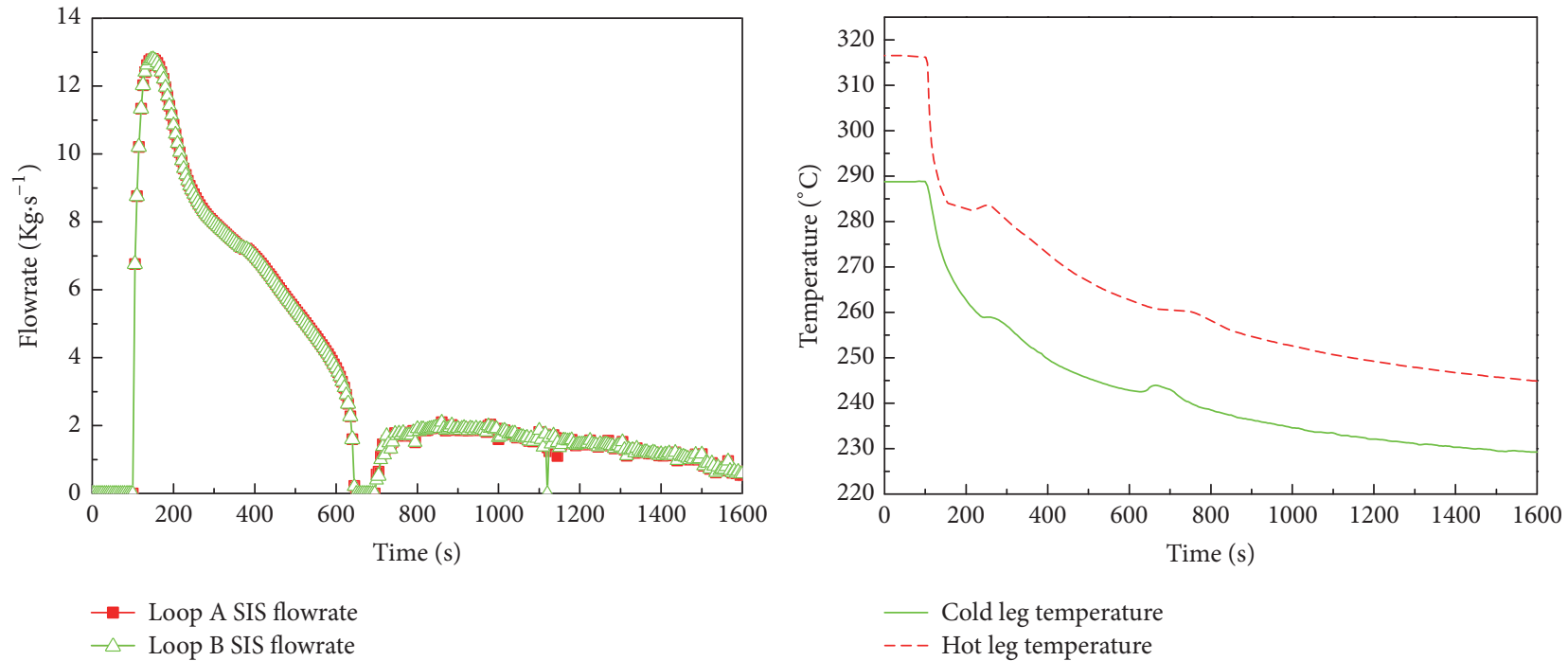

FIgURE 4: Variations of SIS flow rate and coolant temperature versus time.
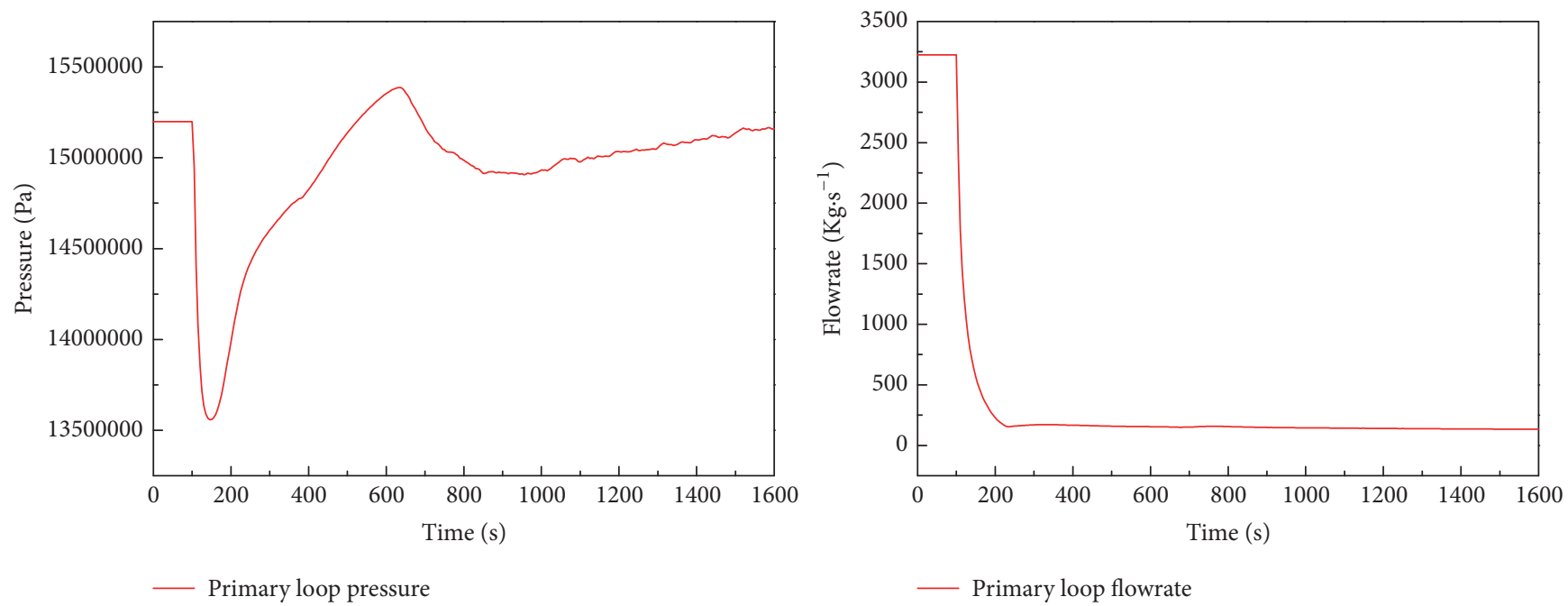

FIGURE 5: Variations of primary loop pressure and flow rate versus time.
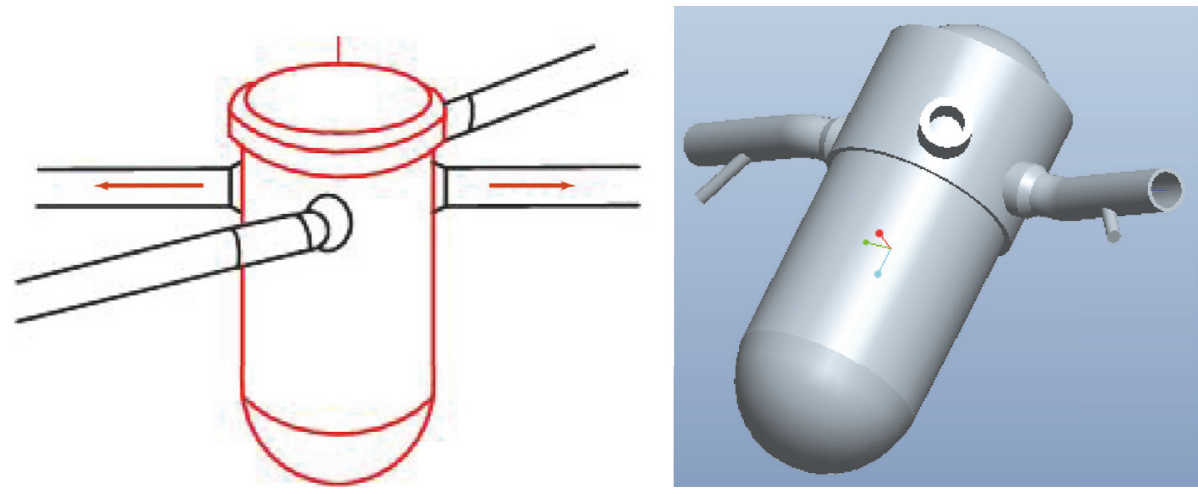

FIGURE 6: The whole geometry of main pipes and RPV. 


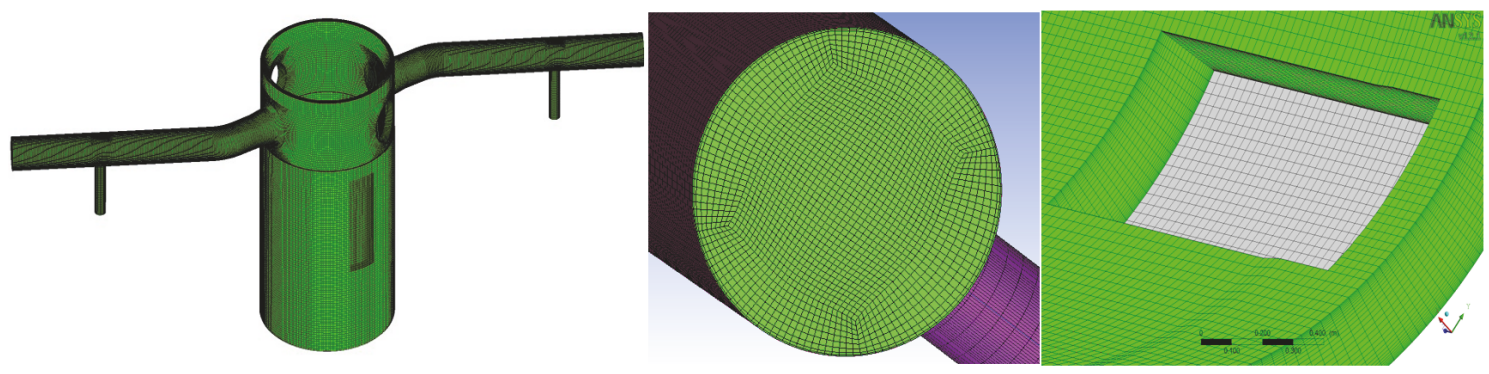

FIGURE 7: Grid of the main pipes and upper section of downcomer.

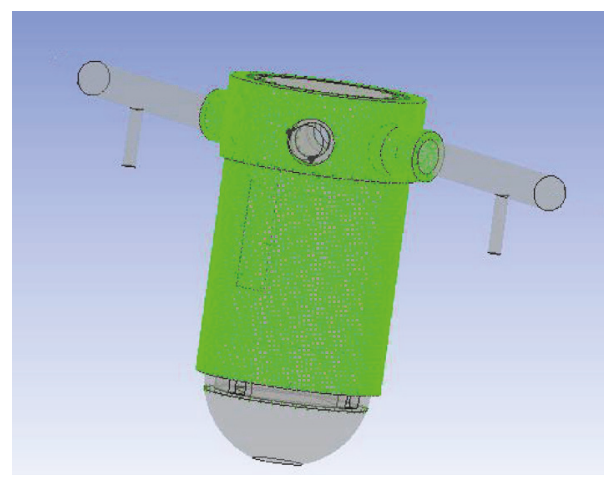

FIgURE 8: The grid of RPV.
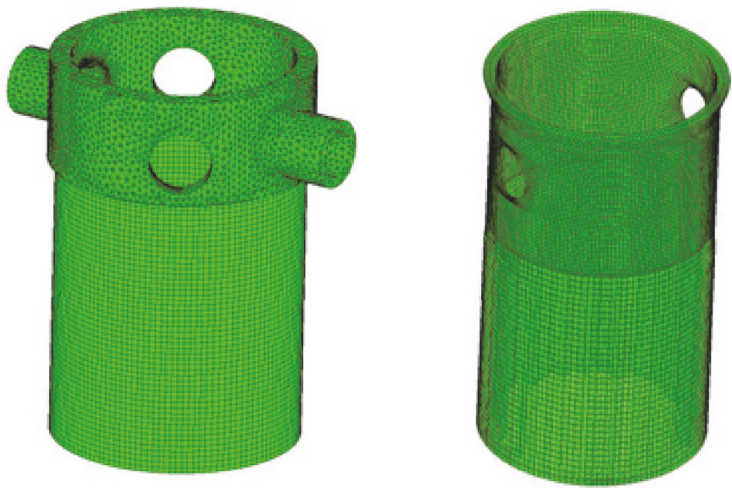

FIGURE 9: Grid of the core barrel.

nozzles, and downcomer fluid region, as shown in Figure 7. The CFD Best Practice Guidelines are intended to help researchers in solving heat transfer and flow problems effectively and accurately using CFD method. Following the Best Practice Guidelines for the use of CFD in Nuclear Reactor Safety Applications [16], the independent grid was achieved and the number of grids was about 2.0 million based on the mesh sensitivity study. The radiation regulatory segment was divided separately, and then the drag coefficient was set.

For the solid region, the mesh of pressure vessel was divided into two parts. The tetrahedral mesh was employed in the upper part, while hexahedral mesh was used in the lower part. Since the mass conservation, momentum conservation, and turbulence equations were not solved in the solid region, no large number of grids were required in this part. The detailed mesh condition is shown in Figures 8 and 9.

4.3. Mathematic Model. For the three-dimensional flow and heat transfer study, the continuity equation, momentum conservation equation, and energy conservation equation were established.

The continuity equation is

$$
\frac{\partial \overline{u_{i}}}{\partial x_{i}}=0 .
$$




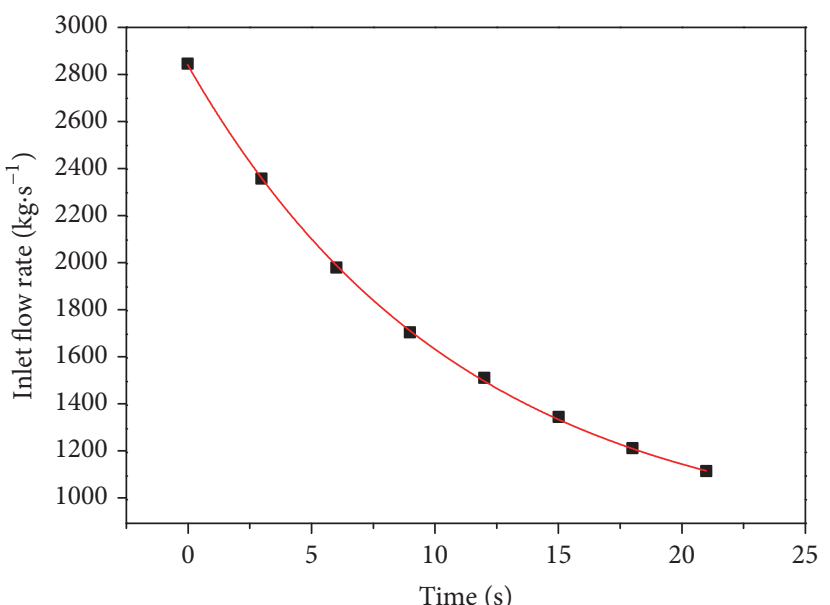

- RELAP5 value - Fitted curve

(a) Inlet flow rate

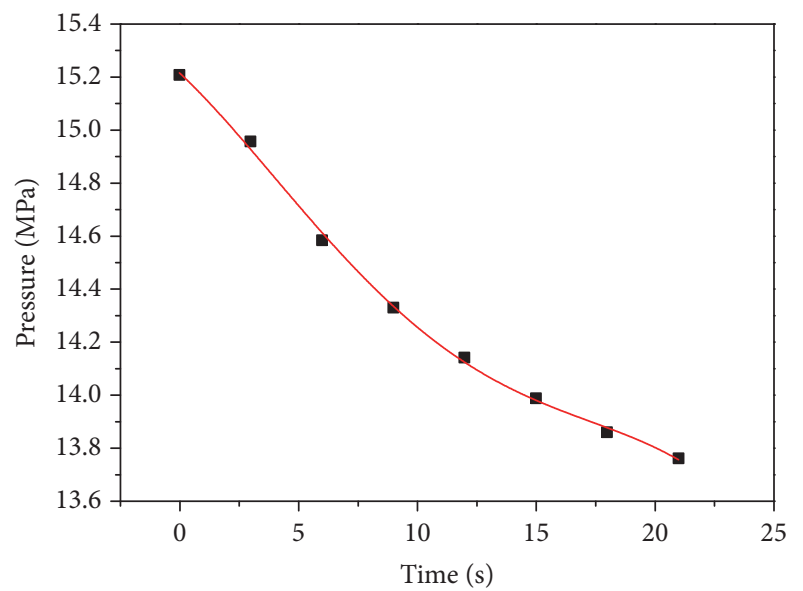

- RELAP5 value

- Fitted curve

(c) Pressure

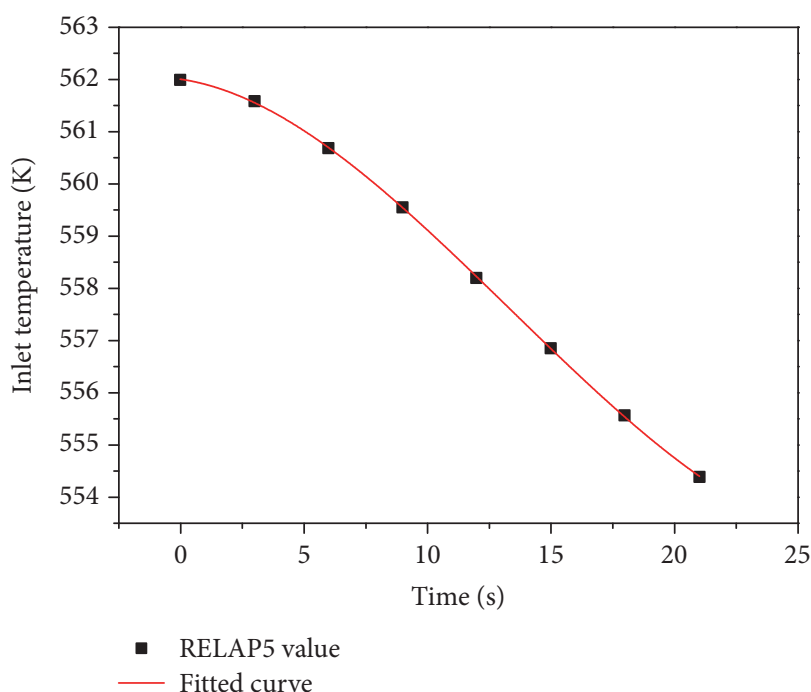

(b) Inlet temperature

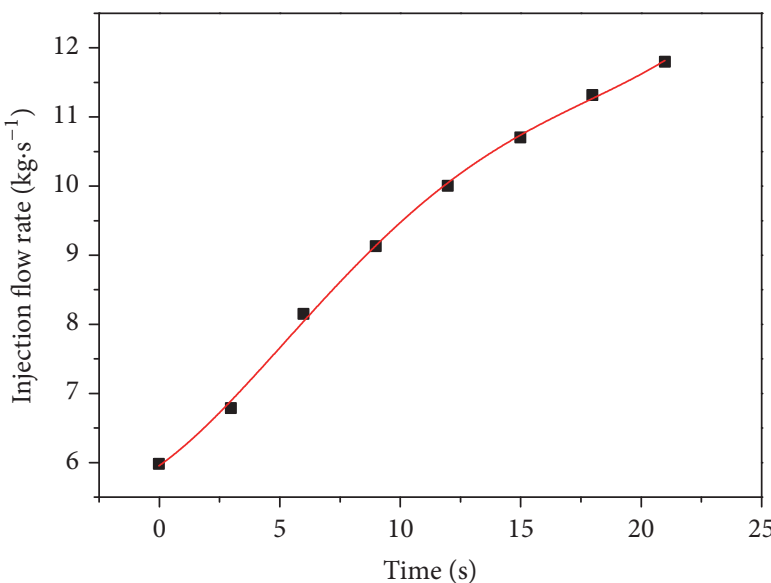

- RELAP5 value - Fitted curve

(d) Injection flow rate

FIGURE 10: Fitted boundary conditions from $102 \mathrm{~s}$ to $123 \mathrm{~s}$.

Momentum conservation equation is

$$
\frac{\partial \bar{u}_{i}}{\partial t}+\frac{\partial \bar{u}_{i} \bar{u}_{j}}{\partial x_{i}}=-\frac{1}{\rho} \frac{\partial \bar{p}}{\partial x_{i}}+\frac{\partial}{\partial x_{j}}\left(\nu \frac{\partial u_{i}}{\partial x_{j}}-\overline{u_{i}^{\prime} u_{j}^{\prime}}\right)
$$

where $-\overline{u_{i} u_{j}}$ is the Reynolds stress term.

Energy conservation equation is

$$
\frac{\partial}{\partial \tau}(\rho T)=\nabla \cdot\left[\left(\frac{\mu}{P_{r}}+\frac{\mu_{t}}{\sigma_{T}}\right) \nabla T\right]+S_{T}
$$

where $\mu / P_{r}$ represents the molecular diffusion while $\mu_{t} / \sigma_{T}$ is the turbulent fluctuation diffusion. The thermal diffusion coefficient is composed of molecular diffusion and turbulent fluctuation diffusion.
The energy conservation equation in solid region is

$$
\frac{\partial(\rho T)}{\partial \tau}=\operatorname{div}\left(\frac{\lambda}{c_{p}} \operatorname{grad} T\right)+S_{T}
$$

where $\rho$ is the density, $\lambda$ is the thermal conductivity, $c_{p}$ thermal capacity, and $S_{T}$ is the energy source term.

There were several turbulent models in the ANSYSCFX, and the well-known single-phase turbulence models are usually used to model turbulence of the liquid phase in Eulerian-Eulerian multiphase simulations. Based on the applicability of different turbulent models, the $k-\varepsilon$ model was used for the subsequent analysis. The turbulent fluctuation kinetic energy $k$ and kinetic energy dissipation rate $\varepsilon$ were achieved through the following equations:

$$
\frac{\partial\left(\rho k v_{i}\right)}{\partial x_{i}}=\frac{\partial}{\partial x_{j}}\left[\left(\mu+\frac{\mu_{t}}{\sigma_{k}}\right) \frac{\partial k}{\partial x_{j}}\right]+P_{k}+G_{b}-\rho \varepsilon,
$$




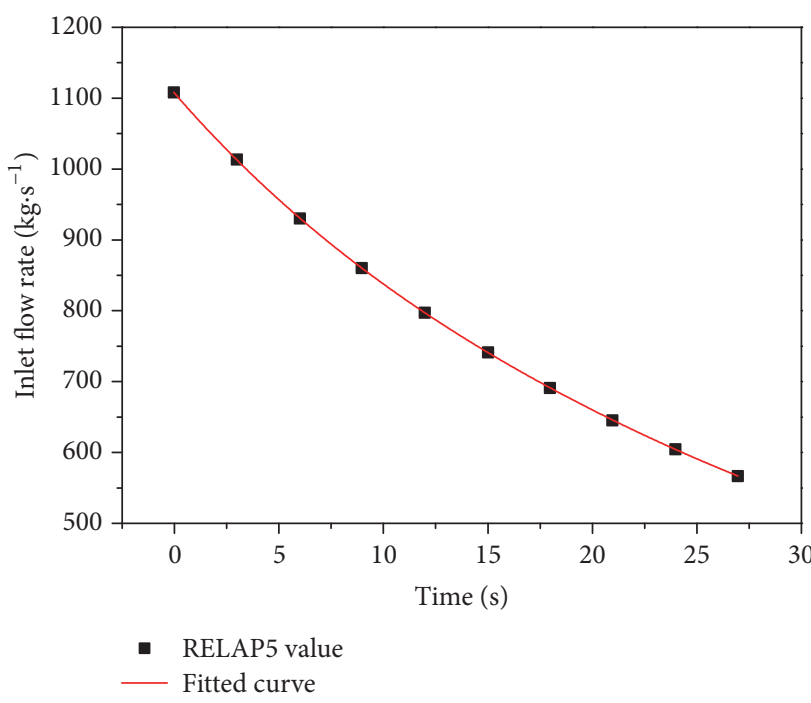

(a) Inlet flow rate

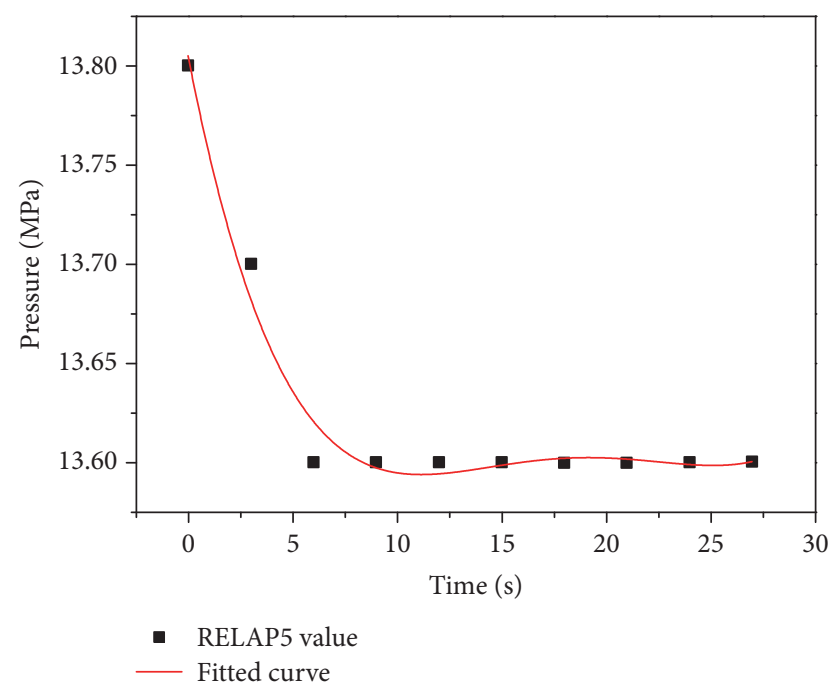

(c) Pressure

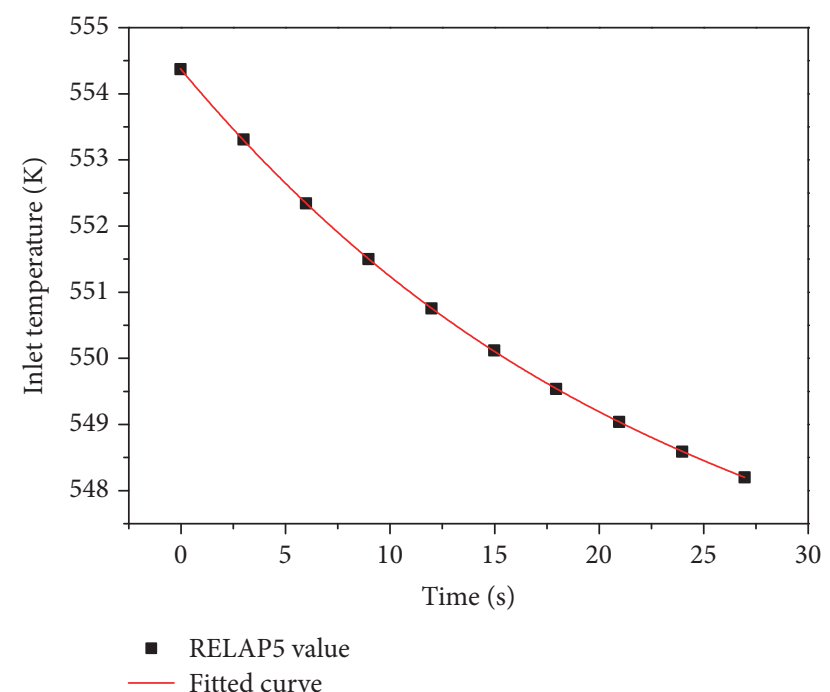

(b) Inlet temperature

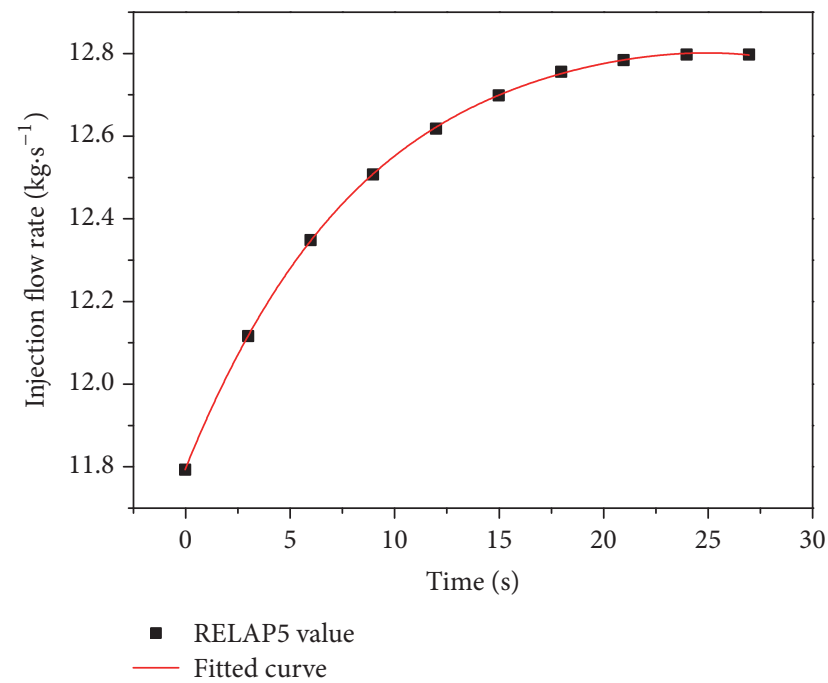

(d) Injection flow rate

FIGURE 11: Fitted boundary conditions from $123 \mathrm{~s}$ to $150 \mathrm{~s}$.

$$
\begin{aligned}
\frac{\partial\left(\rho \varepsilon v_{i}\right)}{\partial x_{i}}= & \frac{\partial}{\partial x_{j}}\left[\left(\mu+\frac{\mu_{t}}{\sigma_{k}}\right) \frac{\partial \varepsilon}{\partial x_{j}}\right] \\
& +C_{1 \varepsilon} \frac{\varepsilon^{2}}{k}\left(P_{k}+C_{3 \varepsilon} G_{b}\right)-C_{2 \varepsilon} \frac{\varepsilon^{2}}{k}
\end{aligned}
$$

where $\mu_{t}$ is the turbulence viscosity coefficient, $C_{3 \varepsilon}$ represents the effect of coolant flow direction on the production of turbulent kinetic energy, and $C_{3 \varepsilon}$ is equal to 1.0 in case that the main coolant flow direction is vertical to the gravity direction, while $C_{3 \varepsilon}$ is equal to 0.0 in case that the main coolant flow direction is parallel to the gravity direction.

$$
\begin{aligned}
\mu_{t} & =\rho C_{\mu} \frac{k^{2}}{\varepsilon}, \\
C_{3 \varepsilon} & =\tanh \left|\frac{u_{/ / g}}{u_{\perp g}}\right| .
\end{aligned}
$$

The production term of turbulent kinetic energy is

$$
P_{k}=-\rho \overline{v_{i}^{\prime} v_{j}^{\prime}} \frac{\partial v_{j}}{\partial x_{i}} .
$$

$G_{b}$ is the kinetic energy caused by the buoyancy.

$$
G_{b}=\beta \frac{\mu_{t}}{\operatorname{Pr}_{t}} g_{j} \frac{\partial T}{\partial x_{i}} .
$$

4.4. Fluid-Structure Interaction Model. The conjugate heat transfer method was adopted in order to simulate the fluidstructure interaction process. The solid conduction and convective heat transfer in pressure vessel are taken into consideration. The governing equations were established for each physical region during boundary coupling implementation. The temperature continuation and heat flux continuation boundary conditions were employed in this study. 


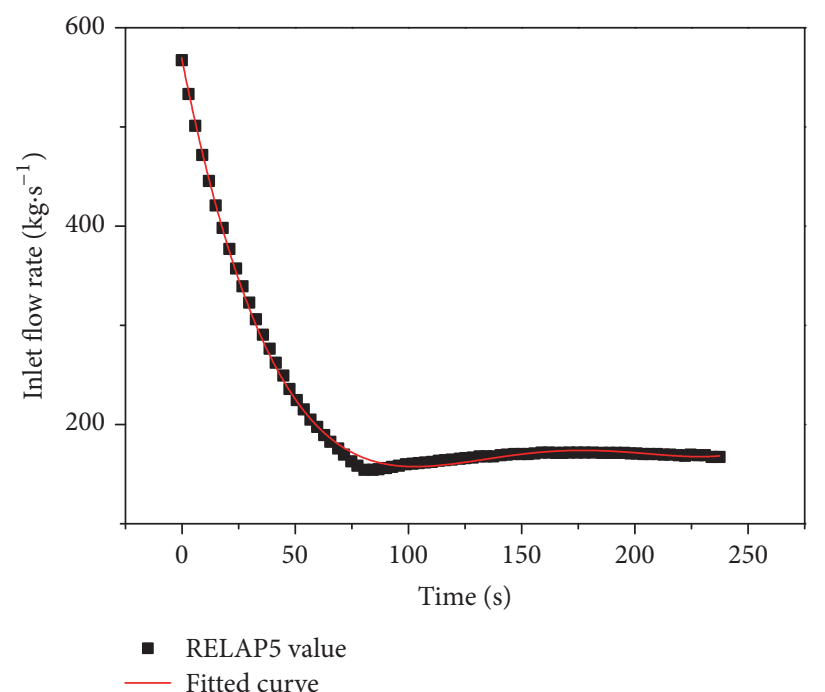

(a) Inlet flow rate

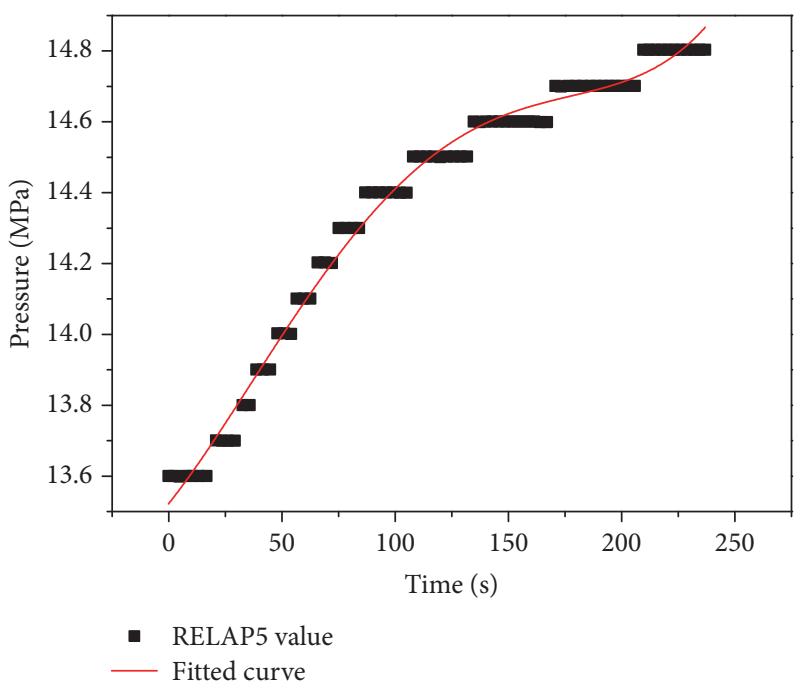

(c) Pressure

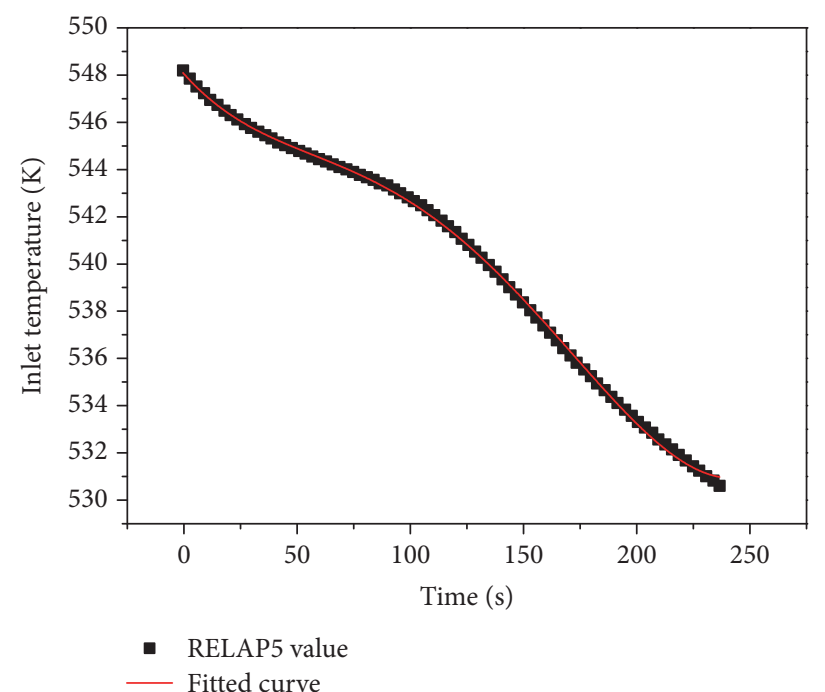

(b) Inlet temperature

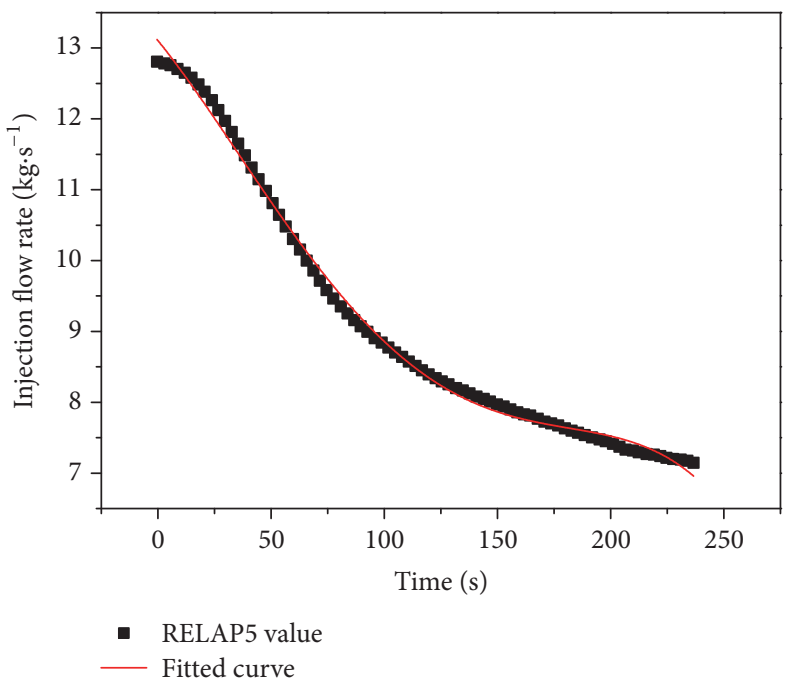

(d) Injection flow rate

FIGURE 12: Fitted boundary conditions from $150 \mathrm{~s}$ to $186 \mathrm{~s}$.

Temperature continuation is

$$
T_{W 1}=T_{W 2}
$$

Heat flux continuation is

$$
q_{W 1}=q_{W 2}
$$

4.5. Boundary Conditions. The initial accident scenario was divided into three parts due to the parameter variation principle. The time intervals were $102 \mathrm{~s}-123 \mathrm{~s}, 123 \mathrm{~s}-150 \mathrm{~s}$, and $150 \mathrm{~s}-186 \mathrm{~s}$, respectively. Then, in each time interval, the CFD simulation boundary and initial conditions were input using fitted polynomials based on the system analysis results. Figures 10, 11, and 12 show the fitted boundary conditions in each time interval. The most conservative injection water temperature was assumed to be $283.15 \mathrm{~K}$.
4.6. Inadvertent Safety Injection System Operation Analysis. Based on the above boundary conditions, mathematical models, the detailed solid region temperature distribution characteristics of RPV wall were studied in this section. Figures 13 and 14 show the RPV solid region temperature distributions at $102 \mathrm{~s}$ and $103 \mathrm{~s}$, respectively. The Safety Injection System was put into operation by mistake at $100 \mathrm{~s}$, but the RPV solid region temperature did not have great variation in the first several seconds. The solid region temperature was within the range of $561 \mathrm{~K}-562 \mathrm{~K}$. The temperature difference is relatively small (about $0.8 \mathrm{~K}$ ). The small temperature difference was mainly caused by the weak "stratification" and the nonisothermal crossing section effect. Also, the temperature distribution was not uniform due to the coolant counterclockwise rotating along the pressure vessel.

Figure 15 shows the RPV solid region temperature distribution at $110 \mathrm{~s}$. The RPV solid region temperature was 

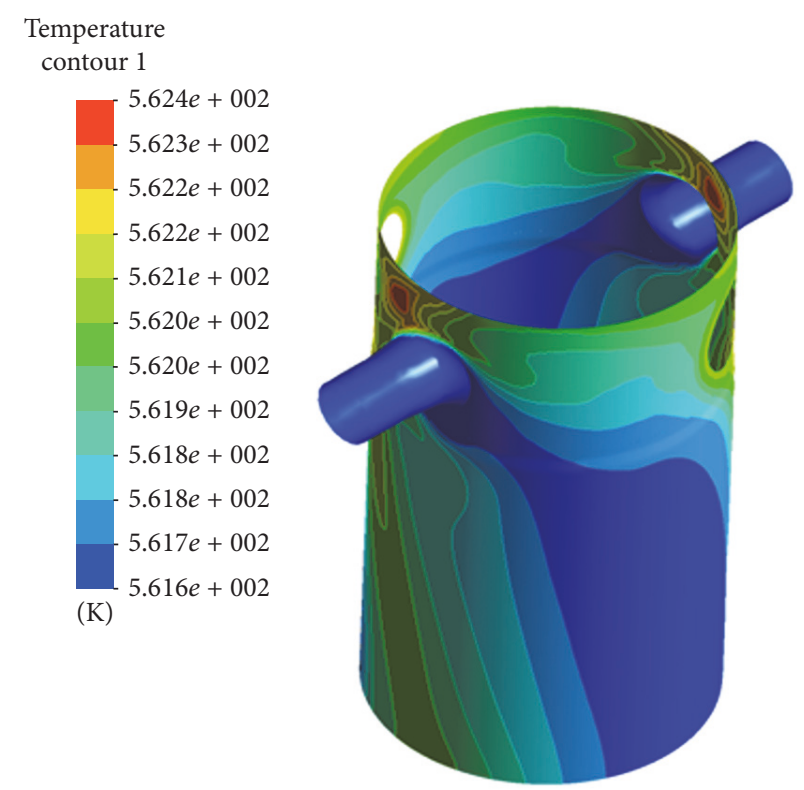

(m)

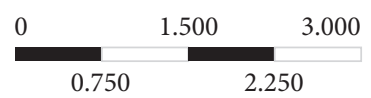

FIGURE 13: Temperature distribution of RPV wall at $102 \mathrm{~s}$.
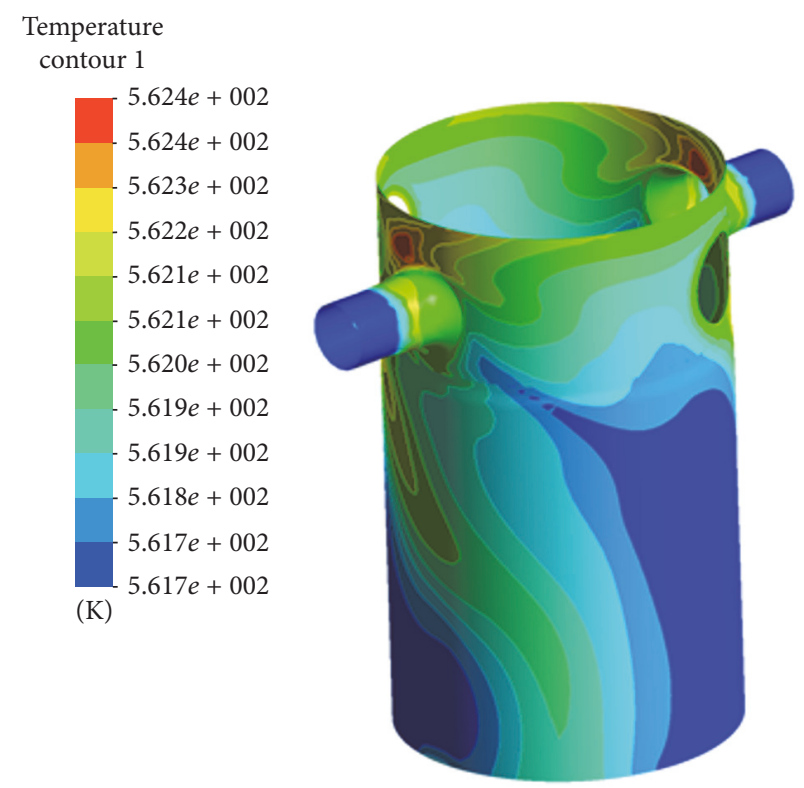

(m)

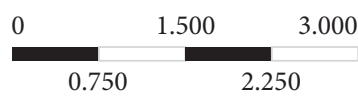

FIGURE 14: Temperature distribution of RPV wall at $103 \mathrm{~s}$.

affected by the cold water from Safety Injection System and the vessel wall temperature decreased gradually. The lowest temperature of solid region decreased and the temperature gradient increased with time. The local temperature of nozzle region decreased to the $553 \mathrm{~K}$ at $110 \mathrm{~s}$. The injection water flow rate reached the maximum value at about $150 \mathrm{~s}$. The detailed three-dimensional temperature distributions of inlet nozzles and RPV wall at $150 \mathrm{~s}$ were shown as Figure 16. The significant temperature decreased in inlet nozzle region could be found. The lowest temperature was about $495 \mathrm{~K}$ and the approximate $70 \mathrm{~K}$ temperature difference was generated. Figure 17 shows the RPV wall temperature distribution at $185 \mathrm{~s}$. 

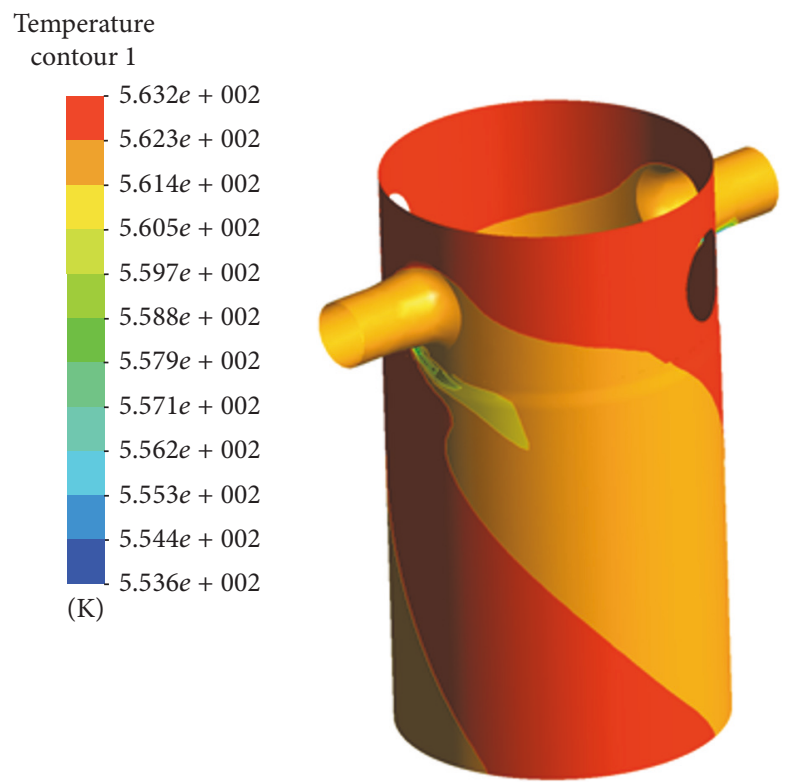

(m)

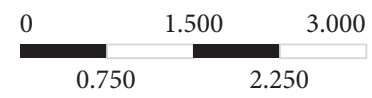

FIgURE 15: Temperature distribution of RPV wall at $110 \mathrm{~s}$.
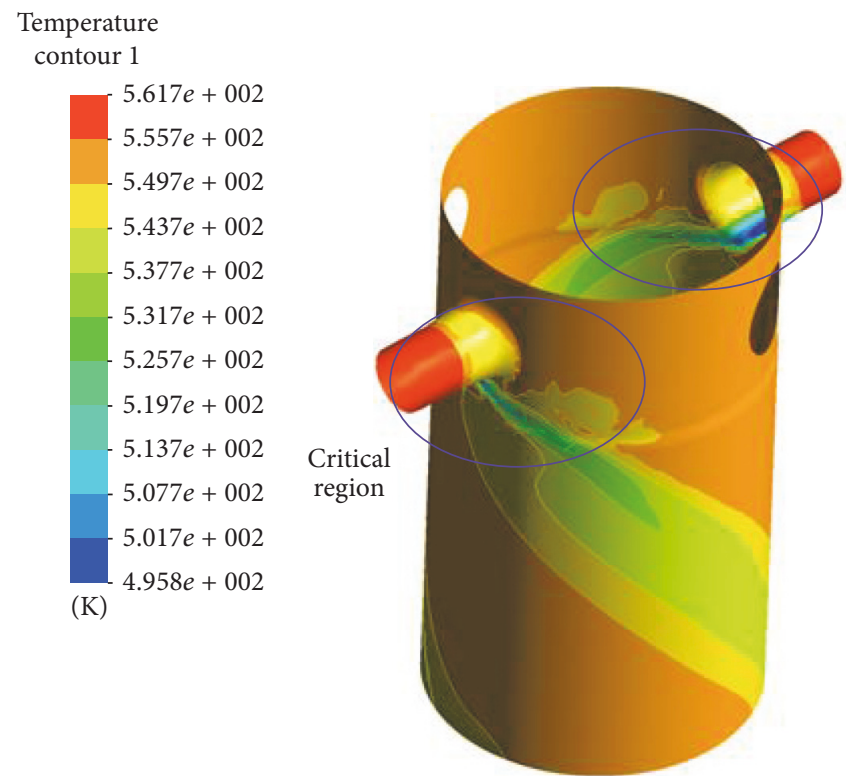

(m)

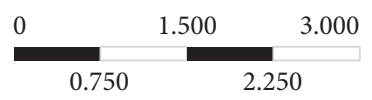

FIGURE 16: Temperature distribution of the RPV wall at $150 \mathrm{~s}$.

During $150 \mathrm{~s}$ to $185 \mathrm{~s}$, the injection water flow rate decreased from the maximum value. As illustrated from the results, the coolant counterclockwise rotated along the pressure vessel and the cold coolant was concentrated. The temperature of cold coolant center decreased with time and the maximum temperature difference was around $80 \mathrm{~K}$.

Figure 18 shows the Safety Injection System coolant temperature distribution in the scenario of inadvertent Safety 


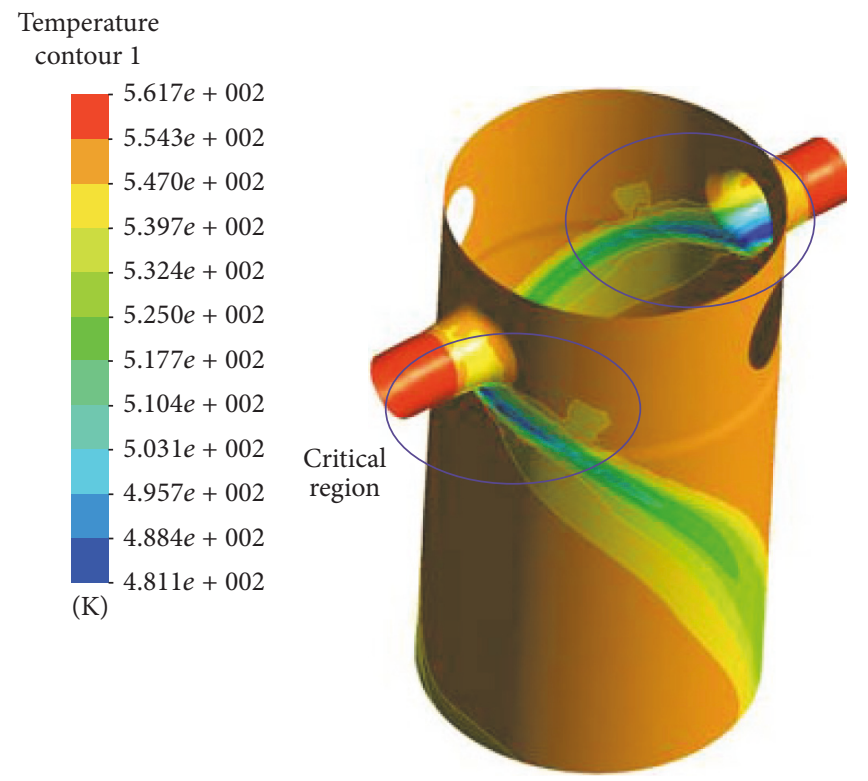

(m)

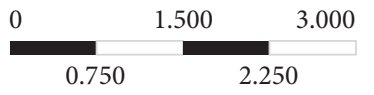

FIGURE 17: Temperature distribution of the RPV wall at $185 \mathrm{~s}$.

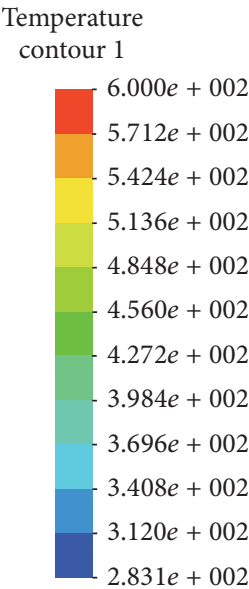

(K)
(K)

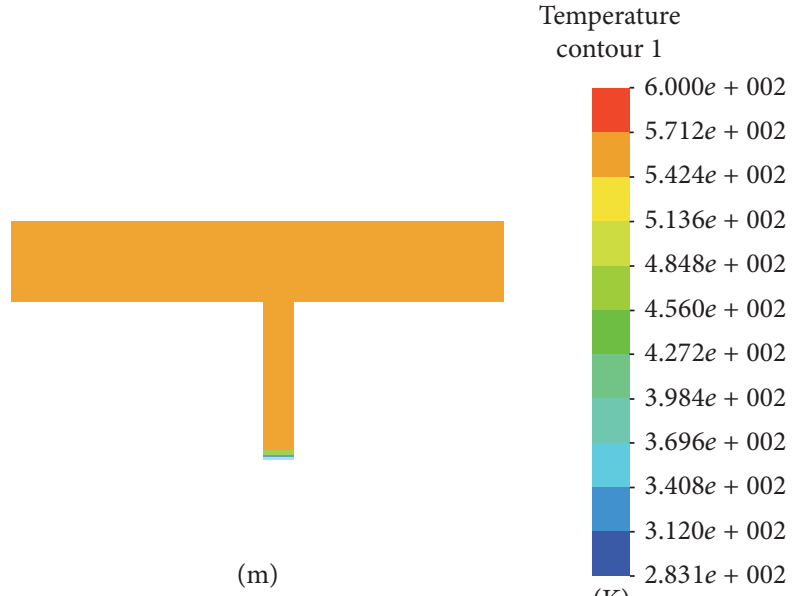

0 0.500
1.000

$$
1.500
$$

(a) $102 \mathrm{~s}$
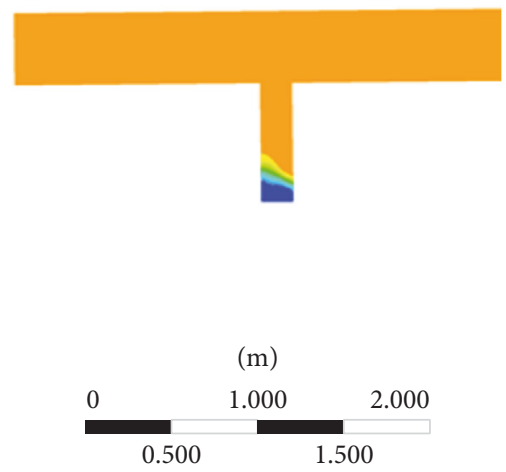

(b) $104 \mathrm{~s}$

FIgURE 18: Temperature distribution of the T-junction in the first phase.

Injection System operation at the initial 4 seconds. The Safety Injection System started to inject cold water at $102 \mathrm{~s}$. The coolant gradually flowed to the main pipe of primary loop.

As could be seen from Figure 19, the coolant from safety injection and the main coolant were fully blended at 111 seconds. The Safety Injection System pipe was full of coolant at 123 seconds and the Safety Injection System water mixed with coolant in the main pipes and flowed into the vessel together.

\section{Conclusions}

In this work, the multiscale method was implemented for the Chashma NPP thermal hydraulic study under the inadvertent Safety Injection System operation scenario. A fine model of primary loop and Safety Injection System was established using system analysis code RELAP5 and then the transient scenario was simulated. The transient variations of important thermal hydraulic parameters were achieved and 


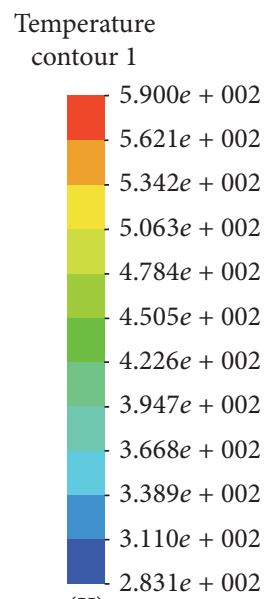

(K)

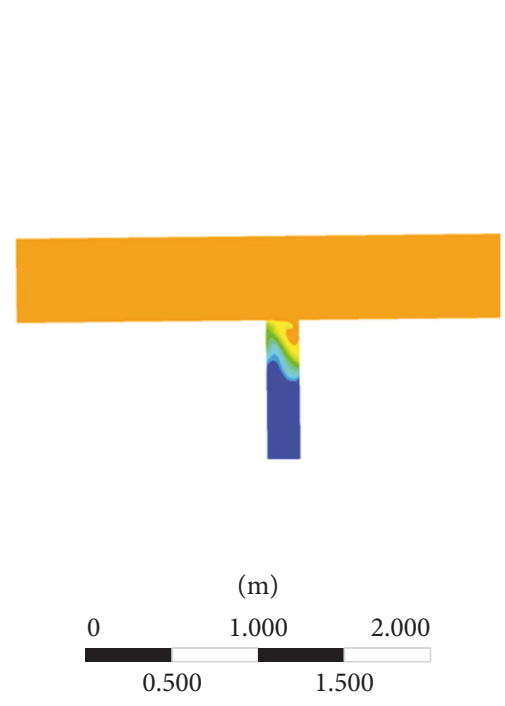

(a) $109 \mathrm{~s}$

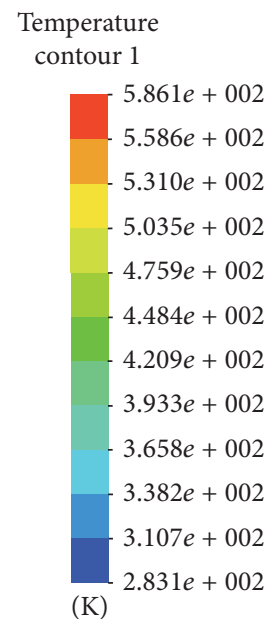

(K)

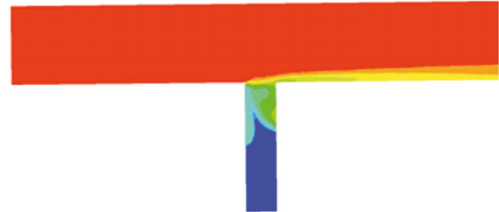

(m)

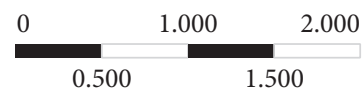

(b) $111 \mathrm{~s}$

Temperature
contour 1

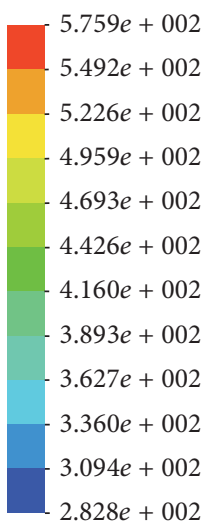

(K)

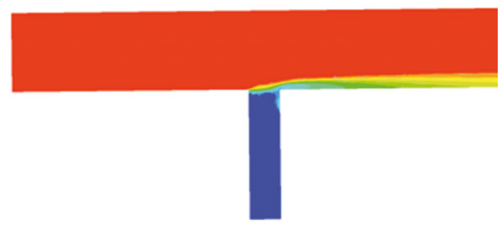

$(\mathrm{m})$

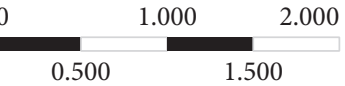

FIgURE 19: Temperature distribution of the T-junction in the second phase.

investigated. The injected coolant mass flow rate increased sharply and then dropped gradually due to the increase of primary loop pressure. The maximum injection flow rate from Safety Injection System was about $13 \mathrm{~kg} / \mathrm{s}$ during this scenario.

The detailed primary loop inlet nozzles and RPV geometries were established using three-dimensional method. The one-dimensional safety analysis results were fitted and imported to the CFD code as the initial and boundary conditions. Based on this model, the variations of RPV wall temperature distribution with time were achieved under the inadvertent Safety Injection System operation scenario for Chashma NPP. The maximum temperature difference was about $80 \mathrm{~K}$ and the most critical region was marked. The detailed three-dimensional thermal hydraulic simulation results provide the necessary input conditions for threedimensional stress analysis for PTS study.

The multiscale simulation method could provide an effective and precise approach for the PWR PTS thermal hydraulic study. It is of great significance and meaningful for the reactor key equipment structure assessment and lifetime fatigue research.

\section{Conflicts of Interest}

The authors declare that they have no conflicts of interest.

\section{Acknowledgments}

This research has been supported by National Natural Science Foundation of China (no. 11705139). 


\section{References}

[1] B. R. Bass, C. E. Pugh, J. Sievers, and H. Schulz, "Overview of the international comparative assessment study of pressurized thermal-shock in reactor pressure vessels (RPV PTS ICAS)," International Journal of Pressure Vessels and Piping, vol. 78, no. 2-3, article 2132, pp. 197-211, 2001.

[2] D. Lucas, D. Bestion, E. Bodèle et al., "An overview of the pressurized thermal shock issue in the context of the NURESIM project," Science and Technology of Nuclear Installations, vol. 2009, Article ID 583259, 13 pages, 2009.

[3] V. Petrov and A. Manera, "Validation of star-ccm+ for bouyancy driven mixing in a pwr reactor pressure vessel," in Proceedings of the NURETH-14, Ontario, Canada, September 2011.

[4] V. Petrov and A. Manera, "Effect of pump-induced cold-leg swirls on the flow field in the RPV of the EPR ${ }^{\mathrm{TM}}$ : CFD investigations and comparison with experimental results," Nuclear Engineering and Design, vol. 241, no. 5, pp. 1478-1485, 2011.

[5] P. Coste, J. Pouvreau, J. Laviéville, and M. Boucker, "A two-phase CFD approach to the pts problem evaluated on cosi experiment," in Proceedings of the 16th International Conference on Nuclear Engineering (ICONE16 '08), pp. 573-581, Orlando, Fla, USA, May 2008.

[6] N. Mérigoux, J. Laviéville, S. Mimouni, M. Guingo, C. Baudry, and S. Bellet, "Verification, validation and application of NEPTUNE_CFD to two-phase Pressurized Thermal Shocks," Nuclear Engineering and Design, vol. 312, pp. 74-85, 2017.

[7] P. Coste, J. Laviéville, J. Pouvreau, C. Baudry, M. Guingo, and A. Douce, "Validation of the large interface method of NEPTUNE CFD 1.0.8 for pressurized thermal shock (PTS) applications," Nuclear Engineering and Design, vol. 253, pp. 296-310, 2012.

[8] P. Coste, J. Pouvreau, C. Morel et al., "Modeling turbulence and friction around a large interface in a three-dimension two-velocity Eulerian code," in Proceedings of the 12th International Meeting on Nuclear Reactor Thermal Hydraulics (NURETH-12), Pittsburgh, Pa, USA, September 2007.

[9] K. Onizawa, K. Shibata, K. Osakabe, and K. Tanaka, "Improvements to PFM analysis code PASCAL and some case studies on RPV integrity during pressurized thermal shock," in Proceedings of the ASME 2006 Pressure Vessels and Piping/ICPVT-11 Conference, Vancouver, Canada, July 2006.

[10] C. Jang, "Treatment of the thermal-hydraulic uncertainties in the pressurized thermal shock analysis," Nuclear Engineering and Design, vol. 237, no. 2, pp. 143-152, 2007.

[11] R. Woods, N. Siu, A. Kolaczkowski, and W. Galyean, "Selection of pressurized thermal shock (PTS) transient to include in PTS risk analyses," International Journal of Pressure Vessels and Piping, vol. 78, no. 2-3, pp. 179-183, 2001.

[12] RELAP5/MOD3.3, 2001, RELAP5/MOD3.3, 2001, Code Manual Volume 1: Code Structure, System Models, and Solution Methods NUREG/CR-5535.

[13] RELAP5/MOD3.3, 2001, RELAP5/MOD3.3, 2001, Code Manual Volume V: User's Guidelines NUREG/CR-5535.

[14] ANSYS, ANSYS CFX-Solver Theory Guide, ANSYS Inc., Canonsburg, Pa, USA, 2006.

[15] M. Wang, S. Qiu, W. Tian, G. Su, and Y. Zhang, “The comparison of designed water-cooled and air-cooled passive residual heat removal system for $300 \mathrm{MW}$ nuclear power plant during the feed-water line break scenario," Annals of Nuclear Energy, vol. 57, pp. 164-172, 2013.

[16] NEA, "Best Practice Guidelines for the use of CFD in nuclear reactor safety applications," Tech. Rep., NEA, Singapore, 2007. 


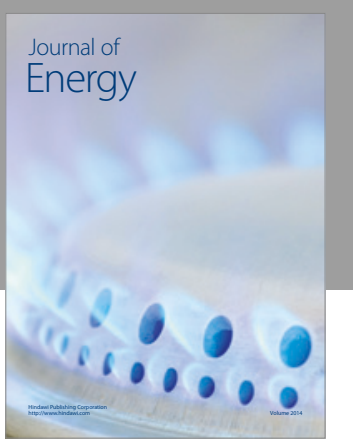

Journal of

Industrial Engineering
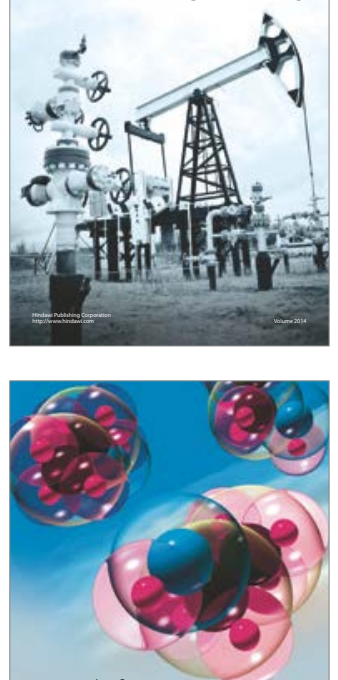

Fuels
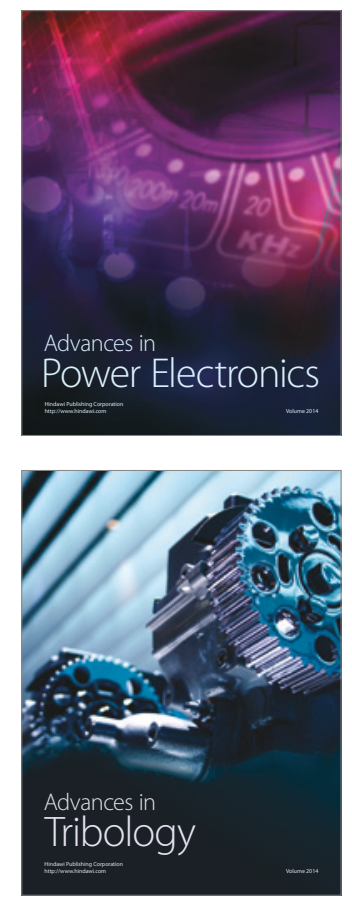
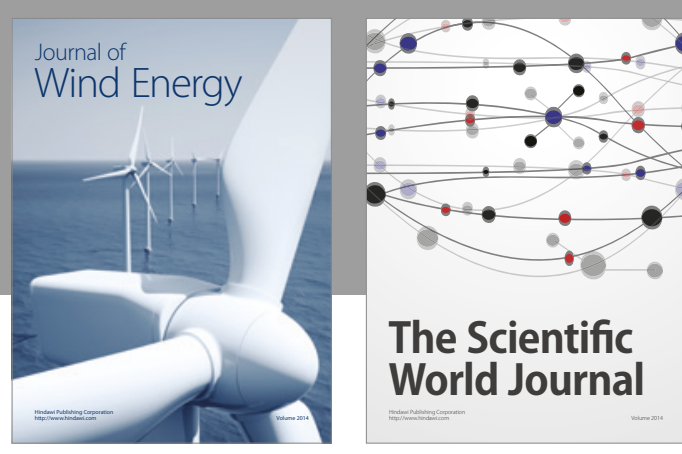

The Scientific World Journal
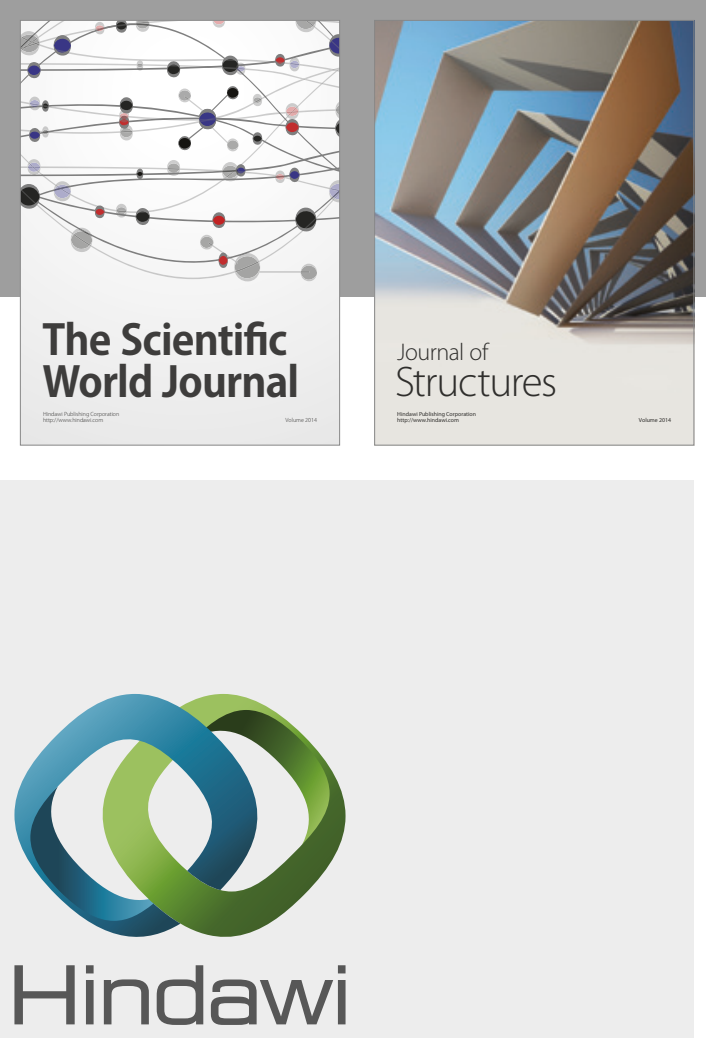

Submit your manuscripts at

https://www.hindawi.com
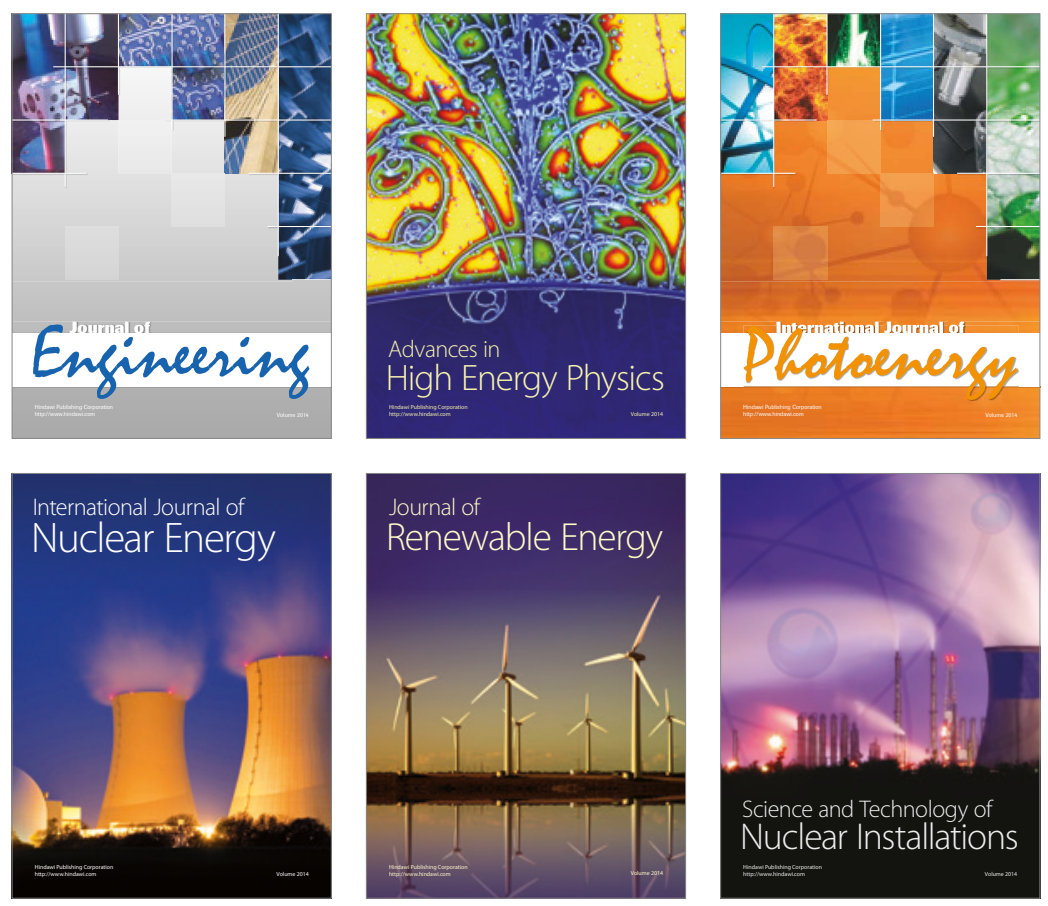

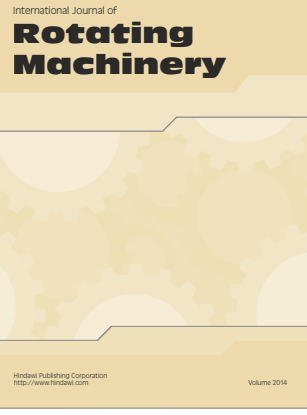

Journal of

Petroleum Engineering

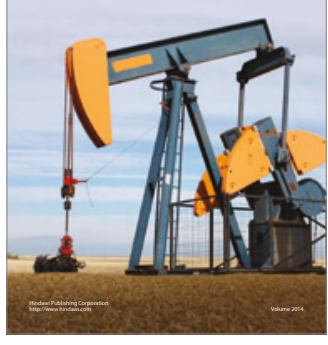

Journal of
Solar Energy
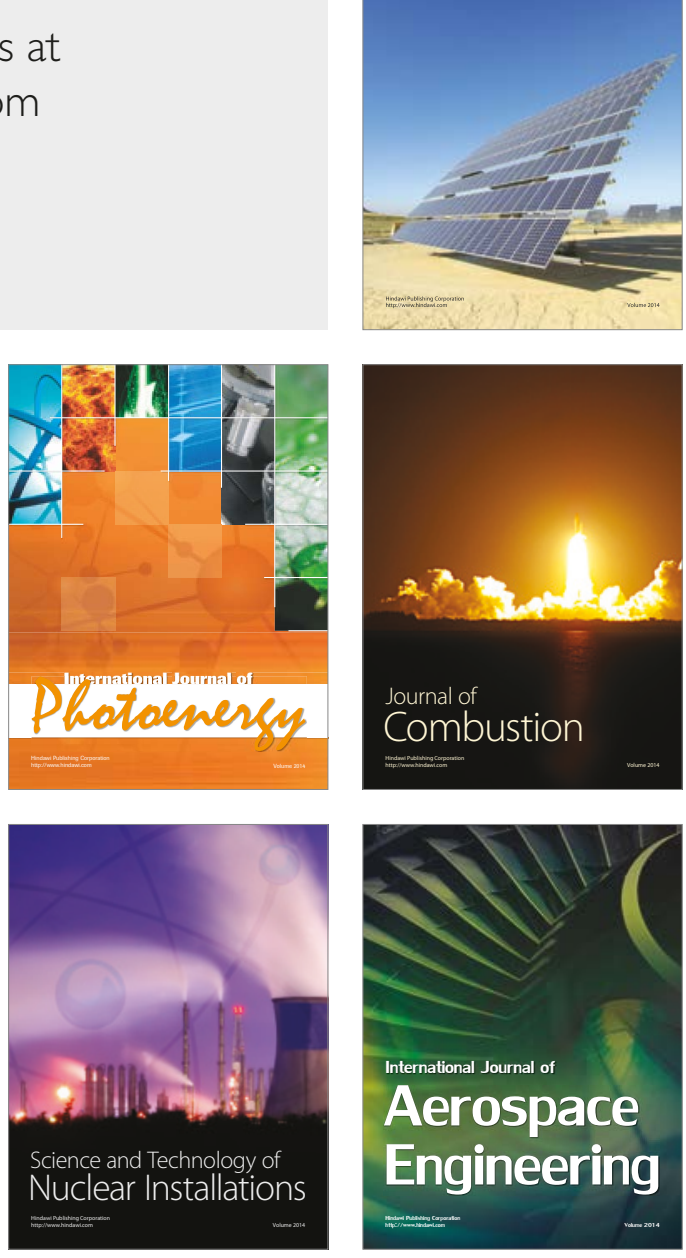